Jurnal Sikola: Jurnal Kajian Pendidikan dan Pembelajaran

VOL. 3 NO. 1 SEPTEMBER 2021

http://sikola.ppj.unp.ac.id

Email: sikola@ppj.unp.ac.id

ISSN: 2686-3413 (Print) 2715-1735 (Online)

DOI: https://doi.org/10.24036/sikola.v3i1.142

\title{
Pengembangan E-Modul Pembelajaran Sosiologi Berbasis Flipbook Maker untuk Peserta Didik Kelas XI IPS SMA
}

\author{
Yulia Wilki Rahayu ${ }^{1}$, Erianjoni Erianjoni ${ }^{2}$ \\ ${ }^{1,2}$ Universitas Negeri Padang
}

Email: yuliawilkirahayu@gmail.com, erianjonisosiologi@gmail.com

\begin{abstract}
Abstrak
Penelitian ini bertujuan untuk menghasilkan bahan ajar dalam bentuk e-modul pembelajaran sosiologi berbasis flipbook maker untuk peserta didik kelas XI IPS SMAN 1 Sawahlunto dan mengungkapkan tingkat validitas dan praktikalitas e-modul yang dikembangkan. Penelitian ini merupakan penelitian dan pengembangan (Researce and Development), model pengembangan yang dipakai yaitu 4D (define, design, develop dan disseminate). Hasil penelitian berdasarkan analisis angket validitas oleh ahli media memperoleh rata-rata 0,83 yang masuk ke dalam kategori "sangat tinggi", hasil analisis angket validitas oleh ahli materi memperoleh rata-rata 0,88 yang masuk ke dalam kategori "sangat tinggi". Hasil angket praktikalitas guru memperoleh rata-rata 0,85 yang masuk ke dalam kategori "sangat tinggi". Sedangkan hasil analisis angket peserta didik memperoleh rata-rata 0,80 yang masuk ke dalam kategori "tinggi". Dengan demikian, hasil analisis data yang diperoleh menunjukkan bahwa e-modul pembelajaran sosiologi berbasis flipbook maker untuk peserta didik kelas XI IPS SMAN 1 Sawahlunto yang dihasilkan valid dan praktis.

Kata kunci: E-Modul, Flipbook Maker, Integrasi Sosial
\end{abstract}

\section{Abstract}

This research aims to produce teaching materials in the form of flipbook maker-based sociology learning e-Modules for class XI IPS students of SMAN 1 Sawahlunto and reveal the level of validity and practicality of the developed eModules. This research is research and development (Research and Development), the development model used is $4 D$ (define, design, develop and disseminate). The results of the study based on the analysis of the validity questionnaire by media experts obtained an average of 0.83 which was included in the "very high" category of validity, the results of the validity questionnaire analysis by material experts obtained an average of 0.88 which entered the "very high" category of validity. The results of the teacher practicality questionnaire obtained an average of 0.85 which falls into the "very high" practicality category. While the results of the questionnaire analysis of students obtained an average of 0.80 which was included in the "high" category. Thus, the results of the analysis of the data obtained indicate that the flipbook makerbased sociology learning e-Module for class XI IPS students of SMAN 1 Sawahlunto is valid and practical.

Keywords: E-Modul, Flipbook Maker, Integrasi Sosial

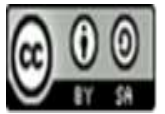

Received: July 19, 2021

Revised: September 28, 2021

Accepted: September 30, 2021

Jurnal Sikola: Jurnal Kajian Pendidikan dan Pembelajaran Vol. 3, No. 1, Th. 2021 


\section{Pendahuluan}

Pendidikan menjadi salah satu patokan kemajuan bangsa dimana majunya kehidupan suatu bangsa sangat memerlukan pendidikan karena tanpa pendidikan suatu negara akan sangat tertinggal dari negara lain. (Sari, Erianjoni, \& Sylvia, 2019). Oleh karena itu peningkatan mutu pendidikan menjadi mutlak harus mutlak dilakukan seiring dengan berkembangnya teknologi dan informasi di abad ke-21. Perkembangan ini mendorong perlunya diciptakan berbagai inovasi dalam pembelajaran agar dapat membentuk individu yang memiliki kompetensi berdaya saing dan berdaya guna.

Kualitas sarana dan prasarana pendidikan terus diperbaiki untuk menyikapi tuntutan abad ke-21, salah satunya merubah kurikulum KTSP menjadi kurikulum 2013. Menurut Henggraini (Henggraini Eka Putri, 2020) kurikulum 2013 menekankan pada kegiatan pembelajaran yang berpusat pada peserta didik (student center learning), peran guru hanya sebagai perantara untuk memberikan stimulus, membangkitkan dan memberikan motivasi agar materi pelajaran dapat dipahami oleh peserta didik. Pembelajaran dalam kurikulum 2013 menuntut keaktifan peserta didik agar dapat belajar secara mandiri. (Shafa, 2014) Oleh karena itu, guru harus bisa merancang kegiatan pembelajaran sebaik mungkin agar pembelajaran lebih bermakna. Penggunaan bahan ajar dalam pembelajaran dapat menarik minat peserta didik, sehingga tujuan pembelajaran dapat tercapai dengan baik (Putri \& Yuniasih, 2020). Berkaitan dengan teknologi informasi yang berkembang bahan ajar yang digunakan oleh guru dapat didukung dengan teknologi dan informasi sehingga peserta didik dapat mengembangkan pengetahuannya di bidang IT sekaligus menghasilkan sumber daya manusia yang berkualitas.

Pembelajaran sosiologi di SMAN 1 Sawahlunto pada semester Januari-Juni 2021 dan dilakukan secara online melalui aplikasi googleclassroom. Hal ini disebabkan karena pandemi covid19 sehingga pemerintah mengeluarkan kebijakan pembelajaran dilakukan secara daring. Kegiatan pembelajaran dilakukan dengan cara guru mengirimkan powerpoint kemudian peserta didik diminta untuk mencatat ke dalam buku catatan atau diprint dan ditempel di buku catatan, setelah itu peserta didik diberi penugasan, dengan pembelajaran yang seperti ini mengakibatkan pembelajaran menjadi tidak maksimal karena peserta didik hanya terfokus untuk memindahkan materi ke dalam buku catatan tanpa memahami materi terlebih dahulu. Selain powerpoint yang diberikan guru, sumber belajar yang juga digunakan oleh peserta didik yaitu internet padahal sumber belajar dari internet belum tentu kebenarannya.

Berdasarkan hasil wawancara dengan guru sosiologi SMAN 1 Sawahlunto, bahan ajar yang biasanya dipakai oleh guru yaitu buku sumber, LKS, dan modul. Modul yang digunakan tersebut belum memuat komponen-komponen yang lengkap dan belum menggunakan teknologi yang sedang berkembang saat ini. Menurut Daryanto (Nurhasikin, Kurnia Ningsih, 2019) sebuah modul memuat komponen-komponen yaitu judul, kata pengantar, daftar isi, peta konsep, petunjuk menggunakan modul, Kompetensi Inti (KI), Kompetensi Dasar (KD), tujuan pembelajaran, materi ajar, lembar kegiatan, evaluasi, glosarium dan daftar pustaka. Hasil obeservasi peneliti, metode yang digunakan oleh guru yaitu ceramah, diskusi, dan tanya jawab melalui aplikasi pembelajaran yang digunakan. Bahan ajar yang digunakan serta metode yang digunakan ternyata belum sepenuhnya membantu peserta didik dalam menemukan konsep secara mandiri. Metode ceramah yang digunakan dapat menimbulkan kebosanan pada peserta didik dalam belajar karena masih berpusat kepada guru, padahal dalam kurikulum 2013 proses pembelajaran dituntut lebih berpusat kepada peserta didik (student center) (Henggraini Eka Putri, 2020), sehingga pembelajaran daring yang dilakukan pada masa pendemi ini menyebabkab peserta didik belum menguasai materi secara maksimal.

Berdasarkan permasalahan yang telah dipaparkan di atas pengembangan sumber belajar yang inovatif dan menarik penting dilakukan. Pengintegrasian berbagai sumber belajar peserta didik dalam bentuk satu modul yang dapat diakses secara online mulai dari materi, penugasan,

Jurnal Sikola: Jurnal Kajian Pendidikan dan Pembelajaran Vol. 3, No. 1, Th. 2021 
LKPD, dan evaluasi menjadikan peserta didik terkoneksi secara konsisten dengan materi yang dipelajari dan dapat menuntun langkah-langkah pengalaman belajar yang diharapkan muncul setelah proses pembelajaran. Salah satu inovasi terhadap sumber belajar yang dapat digunakan oleh peserta didik, adalah modul yang dapat diakses secara online (e-modul) berbasis aplikasi. Emodul yaitu sarana atau alat untuk menyampaikan pembelajaran yang disusun secara sistematis dan menarik yang terdiri dari materi, batasan-batasan, metode dan cara mengevaluasi untuk mencapai tujuan yang diharapkan. (Priyanthi \& Agustini, 2017). Modul elektronik jua dapat menyampaikan informasi dalam bentuk buku elektronik yang dapat disimpan dalam hard disk, disket, CD, atau flashdisk dan dapat dibaca menggunakan komputer atau laptop (Prayudha, 2014). Kelebihan yang dimiliki e-modul yaitu e-Modul dapat dilengkapi dengan audio, video, animasi, gambar dan tes untuk mengetahui kemampuan peserta didik (Suarsana, 2013). Keuntungan belajar menggunakan e-Modul yaitu dapat digunakan secara mandiri dengan bantuan laptop atau komputer sehingga peserta didik memiliki ruang untuk belajar mandiri sesuai dengan tuntutan kurikulum 2013. Penggunaan e-modul juga dapat membuat pembelajaran menjadi lebih efektif karena dapat membantu peserta didik yang mengalami kesulitan belajar (Santika \& Sylvia, 2021).

Sebuah sumber belajar yang inovatif dan menarik bagi peserta didik akan mempermudah peserta didik dalam memahami materi pembelajaran. Salah satu aplikasi dalam mengembangkan modul menjadi bentuk e-modul adalah flipbook maker. Aplikasi flipbook maker merupakan perangkat lunak profesional yang dapat mengubah portable document format (pdf) menjadi buku yang halaman demi halamannya bisa dibuka secara otomatis. Aplikasi ini dapat mengubah tampilan file pdf menjadi lebih menarik sehingga peserta didik dapat membaca dengan merasakan seakan membuka buku secara fisik. Kelebihan yang dimiliki oleh aplikasi ini, yaitu (1) Peserta didik punya pengalaman dari media pembelajaran; (2) Media yang bervariasi dapat menghilangkan kebosanan peserta didik; (3) Sangat baik untuk kegiatan belajar mandiri; (4) Peserta didik tidak mudah bosan dalam belajar karena pengemasannya yang menarik; (5) Penggunaanya bisa tanpa online internet; (6) Mudah dibaca dan dicermati dengan detail karena bisa di zoom; (7) Memiliki fitur pencarian sehingga mudah dalam pencarian kata; (8) Dapat digunakan di komputer, laptop dan sejenisnya. Berdasarkan permasalahan yang ada serta karakteristik yang dimiliki oleh e-modul dan aplikasi flipbook maker, maka pada artikel ini peneliti akan mendeskripsikan hasil penelitian pengembangan e-modul pembelajaran sosiologi berbasis flipbook maker untuk peserta didik kelas XI IPS SMAN, yang telah diuji kelayakan dan kepraktisannya di SMAN 1 Sawahlunto, Provinsi Sumatera Barat.

\section{Metode Penelitian}

Penelitian ini merupakan penelitian dan pengembangan Research and Development (R\&D). Penelitian Research and Development bertujuan untuk membuat suatu produk kemudian menguji kepraktisan dan efektifitas produk tersebut (Sugiyono, 2015). Penelitian ini bertujuan untuk menghasilkan e-Modul pembelajaran sosiologi berbasis flipbook maker dan mengungkapkan tingkat validitas dan praktikalitas e-Modul. Model pengembangan dalam penelitian ini adalah model 4D yang terdiri dari empat tahap yaitu, define, design, develop, dan disseminate. Tempat dan waktu dilaksanakannya penelitian ini yaitu di FIS UNP dan SMAN 1 Sawahlunto pada tahun ajaran 2020/2021. Subjek dalam penelitian ini adalah 2 orang dosen sosiologi FIS UNP dan guru SMAN 1 Sawahlunto sebagai validator dan 36 peserta didik kelas XI IPS 3 SMAN 1 Sawahlunto sebagai subjek praktikalitas. Objek penelitian yaitu e-Modul pembelajaran sosiologi berbasis flipbook maker untuk peserta didik kelas XI IPS SMAN 1 Sawahlunto. Tahapan kegiatan penelitian yang akan dilakukan adalah sebagai berikut:

Tahap pertama define (pendefinisian), tahap pendefinisian merupakan tahap awal pengembangan e-Modul. Langkah-langkah pokok tahap define, yaitu analisis ujung depan, analisis

Jurnal Sikola: Jurnal Kajian Pendidikan dan Pembelajaran Vol. 3, No. 1, Th. 2021 
peserta didik, analisis tugas, analisis konsep dan perumusan tujuan pembelajaran. Tahap kedua design (perancangan) merancang e-Modul pembelajaran sosiologi berbasis flipbook maker yang relevan terhadap hasil pendefinisian. Tahap ketiga develop (pengembangan), merupakan tahap pengembangan untuk menghasilkan e-Modul yang baik dan sudah diperbaiki sesuai dengan masukan para ahli. Tahap develop memiliki empat tahap, yaitu (1) validasi produk, (2) revisi, (3) uji praktikalitas, (4) revisi produk.

Teknik untuk mengumpulkan data, yaitu observasi, angket (kuisioner) dan wawancara. Adapun instrumen untuk mengumpulkan data, yaitu angket validasi ahli media, angket validasi ahli materi, angket praktikalitas guru dan angket praktikalitas peserta didik. Lembar angket diberikan kepada validator, guru dan peserta didik untuk memberikan penilaian terhadap e-Modul yang dikembangkan. Teknik analisis data dalam penelitian ini menggunakan analisis statistik deskriptif untuk mendeskripsikan kevalidan dan kepraktisan e-Modul yang dikembangkan. Data yang diperoleh dari hasil penyebaran angket dianalisis menggunakan Momen Kappa Cohen (Watters, 2008).

Keterangan:

$$
\operatorname{Moment} \operatorname{Kappa}(k)=\frac{\rho_{o}-\rho_{e}}{1-\rho_{e}}
$$

$\mathrm{K}$ : Moment Kappa yang menunjukkan validitas/praktikalitas produk

$\rho_{o} \quad$ : Proporsi yang terealisasi (Observed Agreement), yang dihitung dengan cara:

$$
\rho_{o}=\frac{\text { Jumlah nilai yang diberi validator }}{\text { Jumlah nilai maksimal }}
$$

$\rho_{e} \quad$ : Proporsi yang tidak terealisasi (Expected Agreement), yang dihitung dengan cara:

$$
\rho_{e}=\frac{\text { Jumlah nilai maksimal-jumlah yang diberi validator }}{\text { Jumlah nilai maksimal }}
$$

Momen Kappa (k) memiliki interpretasi nilai sebagai berikut:

Tabel 1. Kategori Penentu Hasil Penilaian Berdasarkan Moment Kappa (k)

\begin{tabular}{cc}
\hline Interval & Kategori \\
\hline $0,81-1,00$ & Sangat tinggi \\
\hline $0,61-0,80$ & Tinggi \\
\hline $0,41-0,60$ & Sedang \\
\hline $0,21-0,40$ & Rendah \\
\hline $0,01-0,20$ & Sangat rendah \\
\hline$<0,00$ & Tidak valid \\
\hline \multicolumn{2}{c}{ Sumber: (Watters, 2008) }
\end{tabular}

\section{Hasil dan Pembahasan}

\section{Hasil Penelitian}

Pengembangan e-modul pembelajaran sosiologi materi integrasi sosial berbasis flipbook maker untuk peserta didik kelas XI IPS SMAN dilakukan mengikuti prosedur penelitian pengembangan dengan menggunakan model $4 \mathrm{D}$. Adapun alur pengembangan menurut model ini mengikuti empat tahap yaitu, define, design, develop, dan disseminate. Berikut hasil pengembangan emodul untuk setiap tahapannya. 


\section{Tahap Define (Pendefinisian)}

Tahap pendefinisian terdiri dari lima langkah pokok, yaitu analisis ujung depan, analisis peserta didik, analisis tugas, analisis konsep dan perumusan tujuan pembelajaran yang diuraikan sebagai berikut.

\section{Analisis Ujung Depan}

Analisis ujung depan bertujuan untuk mengetahui permasalahan yang sedang dialami guru dan peserta didik dalam pembelajaran sosiologi. Peneliti memperoleh informasi bahwa proses pembelajaran dilakukan melalui googleclassroom dengan cara guru memberikan materi berupa powerpoint, meminta peserta didik memindahkan materi tersebut ke dalam buku catatan dan memberi penugasan, sehingga peserta didik tidak paham materi yang dipelajarinya, belum membantu peserta didik dalam menemukan konsep secara mandiri.

\section{Analisis Peserta Didik}

Analisis peserta didik bertujuan untuk mengetahui karakteristik peserta didik sebagai target pembelajaran yang berkaitan dengan kemampuan akademik, psikomotor, serta motivasi belajarnya. Karakteristik peserta didik dapat diketahui melalui pengamatan yang dilakukan selama proses pembelajaran daring di SMAN 1 Sawahlunto. Selama pembelajaran daring peserta didik sering terlambat mengirimkan tugas dan ada peserta didik yang tidak pernah mengirimkan tugas sama sekali. Peserta didik cenderung terfokus untuk memindahkan materi ke dalam buku catatan tanpa dipahami terlebih dahulu. Metode yang digunakan guru menyebabkan peserta didik bosan karena pembelajaran hanya membaca powerpoint dan mencatat. Padahal karakteristik kognitif yang dimiliki oleh peserta didik SMA sudah mampu membayangkan situasi rekaan dan kejadian yang terjadi disekelilingnya, melakukan konstruksi konsep dari fenomena tersebut dan memiliki kemungkinan untuk memprediksi sebab dan penyebab secara abstrak dan mengolahnya menjadi konkret dengan pemikiran logis. Proses pembelajaran yang dilakukan tidak mendorong berkembangnya kemampuan kognitif peserta didik.

\section{Analisis Tugas}

Analisis tugas bertujuan untuk menentukan isi dalam satuan pembelajaran sesuai yang ada pada kurikulum yang menjadi acuan yaitu kurikulum 2013. Analisis tugas pada materi integrasi sosial berupa analisis Kompetensi Dasar (KD), kemudian menentukan indikator pencapaian kompetensi. Adapun materi yang akan dikembangkan dalam e-Modul pembelajaran sosiologi ini yaitu materi integrasi sosial.

\section{Analisis Konsep}

Pada tahap analisis konsep, peneliti mengindentifikasi konsep-konsep penting yang akan dibahas atau diajarkan pada materi integrasi sosial, kemudian disusun secara sistematis dalam bentuk peta konsep.

\section{Analisis Tujuan Pembelajaran}

Selanjutnya pada tahap analisis tujuan pembelajaran, peneliti melakukan perumusan tujuan pembelajaran berdasarkan pada indikator pencapaian kompetensi yang telah diuraikan dan peta konsep yang telah disusun dari hasil analisis konsep. Adapun tujuan pembelajarannya adalah melalui e-modul diharapkan peserta didik terlibat aktif dalam proses pembelajaran, memiliki sikap ingin tahu, memiliki rasa tanggung jawab, teliti, memberi kritik dan saran, menjawab pertanyaan, dan dapat menjelaskan pengertian dan syarat integrasi sosial, menentukan faktor terbentuknya integrasi sosial, menjelaskan proses integrasi sosial dan mendeskripsikan bentuk-bentuk integrasi sosial. Berdasarkan tahap pendefinisian dan lima langkah pokok yang dimilikinya dapat diketahui permasalahan yang ada di SMAN 1 Sawahlunto, sehingga ini menjadi alasan untuk dilakukannya 
Yulia Wilki Rahayu, Erianjoni Erianjoni Pengembangan E-modul Pembelajaran Sosiologi Berbasis Flipbook Maker untuk Peserta Didik Kelas XI IPS SMAN 1 Sawahlunto

penelitian pengembangan e-modul pembelajaran sosiologi berbasis flipbook maker untuk peserta didik kelas XI IPS yang diujicobakan kelayakan dan praktikalitasnya di SMAN 1 Sawahlunto.

\section{Tahap Design (Perancangan)}

Pada tahap ini peneliti merancang e-modul pembelajaran sosiologi berbasis flipbook maker yang didasarkan pada tahap pendefinisian. Tahap design terdiri dari: (1) Pemilihan media yaitu, eModul pembelajaran sosiologi berbasis flipbook maker; (2) Pemilihan format yang disesuaikan dengan komponen-komponen pada e-modul yang terdiri dari: cover, petunjuk belajar (guru dan peserta didik), peta konsep, kompetensi pembelajaran, kegiatan pembelajaran, latihan kegiatan, lembar evaluasi, kunci latihan kegiatan dan evalusi, glosarium dan daftar pustaka; (3) Desain awal, yang bertujuan untuk merancang e-modul menggunakan komputer atau laptop yang diawali dengan membuat desain e-Modul pada software Microsoft Word 2010 kemudian disimpan dalam format PDF. E-Modul dalam format PDF kemudian dimasukkan ke dalam software e-modul, yaitu kvisoft flipbook maker. Setelah itu, e-modul disimpan dalam format .exe. Soal evaluasi pada e-modul dirancang menggunakan aplikasi adobe flash CS6 yang disimpan dalam format swf. Setelah desain e-modul selesai dirancang, peneliti membuat instrumen untuk validasi ahli media, ahli materi, angket praktikalitas guru dan peserta didik. Tampilan e-modul pembelajaran sosiologi berbasis flipbook maker dapat dilihat seperti pada gambar 1 berikut.

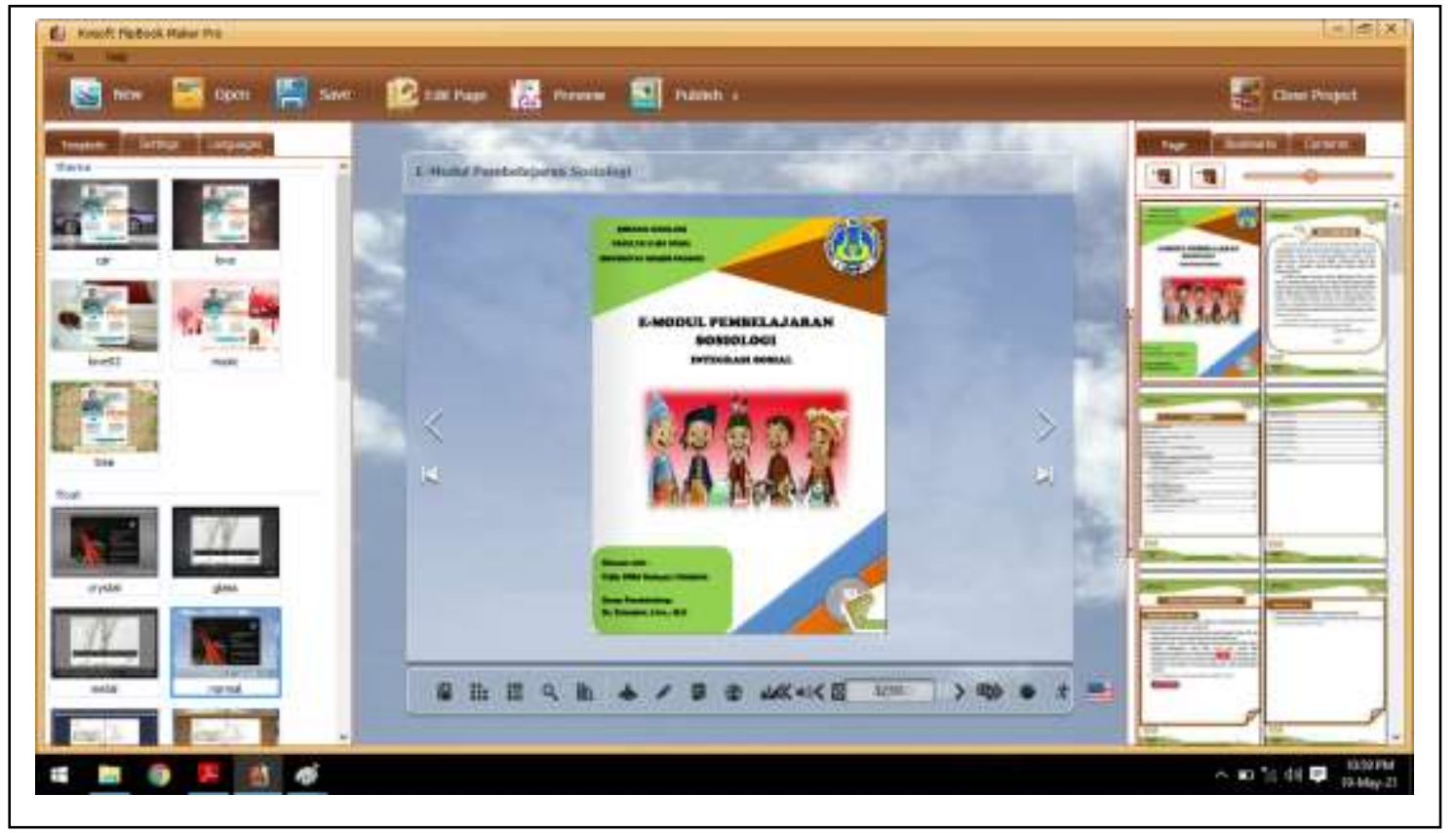

Gambar 1. E-Modul Pembelajaran Sosiologi pada Aplikasi Kvisoft Flipbook Maker

\section{Tahap Develop (Pengembangan)}

Tahap pengembangan merupakan tahap yang bertujuan untuk menghasilkan e-modul yang baik dan sudah melewati proses perbaikan berdasarkan masukan dari para ahli.

\section{Validasi oleh Ahli Media}

Validasi ahli media dilakukan untuk menilai kelayakan produk e-modul yang dilihat dari komponen kegrafikan dan kebahasaan. Adapun validator yang memberikan penilaian terdiri dari dua dosen sosiologi FIS UNP yaitu JN dan Ibu LZ. Berikut disajikan rata-rata hasil penilaian oleh ahli media pada tabel 2 . 
Yulia Wilki Rahayu, Erianjoni Erianjoni Pengembangan E-modul Pembelajaran Sosiologi Berbasis Flipbook Maker untuk Peserta Didik Kelas XI IPS SMAN 1 Sawahlunto

Tabel 2. Rata-rata Hasil Penilaian E-Modul oleh Ahli Media

\begin{tabular}{cccc}
\hline No & Aspek yang dinilai & $\boldsymbol{k}$ & Kategori Kevalidan \\
\hline 1 & Komponen Kegrafikan & 0.86 & Sangat Tinggi \\
\hline 2 & Komponen Kebahasaan & 0.80 & Tinggi \\
\hline & Rata-rata & 0.83 & Sangat Tinggi \\
\hline
\end{tabular}

Sumber: Data Primer (2021)

Tabel 2 menunjukkan bahwa hasil uji validitas oleh validator ahli media terhadap e-modul pembelajaran sosiologi berbasis flipbook maker yang memperoleh rata-rata 0.83 dan masuk dalam kategori "sangat tinggi" yang dilihat dari komponen kegrafikan dan komponen kebahasaan.

Komponen kegrafikan memperoleh nilai sebesar 0,86 dan masuk dalam kategori "sangat tinggi". Penilaian yang diberikan oleh validator tersebut menunjukkan bahwa e-modul pembelajaran sosiologi memiliki jenis dan ukuran huruf yang jelas terbaca, layout atau penampilan cover menarik, serta gambar yang disajikan dapat dilihat dengan jelas. Menurut Prastowo dalam (Nurhasikin, Kurnia Ningsih, 2019) penggunaan gambar pada e-modul dapat mendukung materi sehingga peserta didik akan semakin tertarik dan mengurangi kebosanan dalam mempelajarinya. Berdasarkan hal tersebut gambar-gambar yang digunakan dalam e-modul bermanfaat untuk peserta didik dalam memahami materi pada setiap kegiatan pembelajaran. Penelitian yang dilakukan oleh Renat (Renat \& Novriyanti, 2017) bahwa modul dengan kategori valid menandakan bahwa modul tersebut sudah baik dan menarik yang dibuktikan dengan terpenuhinya aspek penggunaan huruf dan ukuran, layout atau tata letak, ilustrasi, gambar, foto serta desain tampilan.

Komponen kebahasaan pada e-modul berkaitan dengan bentuk dan ukuran huruf agar jelas terbaca, kalimat yang digunakan harus jelas sehingga peserta didik dapat memahaminya dengan mudah, informasi yang disampaikan jelas dan bahasa yang digunakan sesuai dengan kaidah bahasa Indonesia yang baik dan benar. Nilai yang diberikan oleh validator e-modul pembelajaran sosiologi yang dikembangkan memperoleh nilai sebesar 0,80 dan masuk dalam kategori "tinggi". Nilai yang diberikan oleh validator menunjukkan bahwa bentuk dan ukuran huruf yang digunakan pada e-modul memiliki ukuran yang jelas terbaca, informasi yang disampaikan jelas dan bahasa yang digunakan dalam e-modul pembelajaran sosiologi sesuai dengan kaidah Bahasa Indonesia yang baik dan benar, komunikatif dan dan tidak memiliki makna ganda. Hal ini sesuai dengan karakteristik e-modul yakni, user friendly dimana e-modul hendaknya menggunakan bahasa yang mudah dipahami sehingga dapat bersahabat atau akrab dengan pemakainya (Kemendikbud, 2017). Prastowo dalam (Nurhasikin, Kurnia Ningsih, 2019) menjelaskan bahwa kalimat yang digunakan dalam modul disusun secara sederhana, singkat dan efektif agar peserta didik dapat memahaminya dengan baik.

\section{Validasi oleh Ahli Materi}

Validasi ahli materi dilakukan untuk menilai kelayakan e-modul yang dilihat dari komponen isi dan komponen penyajian yang berkaitan dengan ketepatan dan kesesuaian materi pembelajaran pada e-modul dengan kebutuhan pembelajaran. Adapun ahli materi yang memberikan penilaian yaitu guru sosiologi di SMAN 1 Sawahlunto. Berikut disajikan rata-rata hasil validitas oleh ahli materi yang dapat dilihat pada tabel 3 .

Tabel 3. Rata-rata Hasil Penilaian E-Modul oleh Ahli Materi

\begin{tabular}{c|c|c|c}
\hline No & Aspek yang dinilai & $\boldsymbol{k}$ & Kategori Kevalidan \\
\hline 1 & Komonen Isi & 0,89 & Sangat Tinggi \\
\hline 2 & Komponen Penyajian & 0,87 & Sangat Tinggi \\
\hline \multicolumn{2}{r|}{ Rata-rata } & 0,88 & Sangat Tinggi \\
\hline
\end{tabular}

Sumber: Data Primer (2021)

Jurnal Sikola: Jurnal Kajian Pendidikan dan Pembelajaran Vol. 3, No. 1, Th. 2021 
Tabel 3 menunjukkan bahwa hasil validasi dari ahli materi terhadap e-modul pembelajaran sosiologi berbasis flipbook maker memperoleh rata-rata 0,88 dengan interpretasi "sangat tinggi". Aspek yang dinilai oleh ahli materi yaitu, komponen isi dan komponen penyajian.

Komponen isi berkaitan dengan kesesuaian materi dengan kompetensi dasar (KD) dan indikator, kesesuaian soal-soal dengan materi, kebenaran substansi materi pembelajaran dan manfaat untuk menambah wawasan. Komponen isi memperoleh nilai sebesar 0,89 dan masuk dalam kategori "sangat tinggi". Nilai ini menunjukkan bahwa e-modul yang dikembangkan telah layak digunakan dalam proses pembelajaran yang dilihat dari aspek materi yang disajikan dalam e-modul, e-modul yang dikembangkan sudah sesuai dengan tuntutan KD materi integrasi sosial. Menurut (Daryanto, 2014) e-modul yang baik yaitu sesuai dengan kompetensi dasar. Materi yang disajikan dalam e-modul sesuai dengan kemampuan yang dimiliki oleh peserta didik. dan soalsoal yang diberikan berdasarkan pada materi yang dipelajari pada e-modul tersebut. Sesuai dengan penelitian sebelumnya yang menyatakan bahwa bahan e-Modul layak digunakan untuk medukung proses pembelajaran (Winaya, Darmawiguna, \& Sindu, 2017).

Komponen penyajian berkaitan dengan kesesuaian dengan indikator pencapaian kompetensi (IPK), kejelasan soal-soal dan sistematika pada e-modul. Nilai yang diperoleh sebesar 0,87 dan masuk dalam kategori "sangat tinggi", ini menunjukkan bahwa materi yang disajikan sesuai dengan indikator pencapaian kompetensi yang telah dirumuskan. Hal ini sesuai dengan yang dijelaskan oleh (Dewi, 2015) yang menyatakan bahwa materi pembelajaran harus sesuai dengan indikator dan penyusunan indikator secara cermat akan menjadikan pembelajaran lebih efektif untuk mencapai kompetensi yang diharapkan. Soal-soal pada e-modul disusun berdasarkan pada indikator materi integrasi sosial. Komponen-komponen pada e-modul sudah disusun secara sitematis dan sesuai dengan pendapat Daryanto dalam (Nurhasikin, Kurnia Ningsih, 2019) yang menyatakan bahwa komponen modul meliputi judul, kata pengantar, daftar isi, peta konsep, petunjuk penggunaan modul, kompetensi dasar, tujuan pembelajaran, materi, lembar kegiatan, soal evaluasi, glosarium dan daftar pustaka.

\section{Tahap Disseminate (Penyebarluasan)}

Tahap disseminate dalam penelitian ini dilakukan dengan cara mengujicobakan e-modul pembelajaran sosiologi yang dikembangkan kepada peserta didik kelas XI IPS 3 di SMAN 1 Sawahlunto.

\section{Praktikalitas oleh Guru}

Penilaian praktikalitas dilakukan dengan melakukan uji coba terbatas yakni di kelas XI IPS 3. Kepraktisan e-modul yang dikembangkan dilihat dari segi kemudahan penggunaan, efisiensi waktu pembelajaran, dan manfaat penggunaan e-modul. Hasil uji praktikalitas diperoleh melalui pemberian angket kepada guru sosiologi di SMAN 1 Sawahlunto. Berikut disajikan rata-rata hasil penilaian praktikalitas oleh guru ditampilkan pada tabel 4 .

Tabel 4. Rata-rata Penilaian Praktikalitas E-Modul oleh Guru

\begin{tabular}{clcc}
\hline No & \multicolumn{1}{c}{ Aspek yang dinilai } & $\boldsymbol{k}$ & Kategori Kepraktisan \\
\hline 1 & Kemudahan penggunaan & 0,87 & Sangat Tinggi \\
\hline 2 & Efisiensi waktu belajar & 0,73 & Tinggi \\
\hline 3 & Manfaat & 0,96 & Sangat Tinggi \\
\hline \multicolumn{2}{c}{ Rata-rata } & 0,85 & Sangat Tinggi \\
\hline & Sumber: Data Primer (2021) &
\end{tabular}

Tabel 4 menunjukkan bahwa hasil analisis penilaian praktikalitas oleh guru memperoleh rata-rata 0,85 dengan tingkat praktikalitas "sangat tinggi". Berdasarakan rata-rata nilai yang 
diberikan oleh guru menunjukkan bahwa e-modul yang dikembangkan praktis digunakan untuk pembelajaan.

Penilaian pada komponen kemudahaan penggunaan berkaitan dengan petunjuk penggunaan yang mudah dipahami, penyajian materi jelas dan sederhana, keseluruhan isi dari emodul mudah dipahami serta ukuran dan jenis huruf yang mudah dibaca, mudah dioperasikan dan dibawa kemana-mana dan dapat disimpan dalam compact disk atau flashdisk. Nilai yang diperoleh sebesar 0,87 dan termasuk pada kategori "sangat tinggi", ini menunjukan bahwa petunjuk penggunaan dan materi yang disajikan dalam e-modul mudah dimengerti. Huruf yang digunakan pada e-modul jelas terbaca, e-modul mudah untuk dioperasikan, dapat dipakai secara berulang-ulang, dan mudah untuk dibawa karena dapat disimpan dalam compact disk atau flashdisk. Hal ini sejalan dengan penelitian sebelumnya oleh (Wijayanto, 2014) yang menyatakan bahwa emodul dapat disajikan secara elektronik menggunakan hard disk, disket, CD, atau flashdisk. (BNSP, 2013) juga menyatakan bahwa keterbacaan atau bahasa yang digunakan pada bahan ajar merupakan Bahasa Indonesia yang baik dan benar, yang jelas dan mudah untuk dibaca.

Komponen efisiensi waktu belajar memperoleh nilai sebesar 0,73 dan termasuk pada kategori "tinggi". Hal ini menunjukkan bahwa belajar menggunakan e-modul pembelajaran sosiologi efektif dan dapat membantu peserta didik belajar sesuai dengan kemampuan dan kecepatannya masing-masing. Sejalan dengan pendapat (Budhi Oktavia, Rahadian Zainul, Guspatni, 2018) yang menyatakan bahwa e-modul dinilai efisien oleh guru karena peserta didik mudah menggunakannya dalam belajar. Hal ini menunjukkan bahwa e-modul pembelajaran sosiologi yang dikembangkan membantu menyampaikan pembelajaran dengan lebih efisien. Sesuai dengan penelitian sebelumnya yang menyatakan bahwa efisiensi sebuah e-modul yakni dapat digunakan setiap saat (Wulansari \& Sri Kantun, 2018).

Komponen manfaat memperoleh nilai sebesar 0,96 dan termasuk dalam kategori "sangat tinggi", ini menunjukkan bahwa e-Modul pembelajaran sosiologi dapat membantu guru yang berperan sebagai fasilitator dimana guru tidak lagi menyampaikan materi secara berulang-ulang karena dengan bantuan e-modul peserta didik dapat belajar secara mandiri. Sesuai dengan apa yang dijelaskan (Asrial, Syahrial, Maison, \& Kurniawan, 2020) bahwa e-modul bermanfaat bagi guru untuk membantu dalam penyampaian materi pembelajaran serta memfasilitasi peserta didik untuk belajar secara mandiri. Hasil penilaian praktikalitas oleh guru terhadap e-modul pembelajaran sosiologi menunjukkan bahwa e-modul mudah untuk digunakan, efisien dan memiliki manfaat dalam pembelajaran.

\section{Praktikalitas oleh Peserta Didik}

Praktikalitas e-modul pembelajaran sosiologi berbasis flipbook maker dilakukan dengan cara membagikan angket praktikalitas kepada peserta didik kelas XI IPS 3 di SMAN 1 Sawahlunto.

Berikut disajikan rata-rata hasil penilaian praktikalitas oleh peserta didik ditampilkan pada tabel 5.

Tabel 5. Rata-rata Penilaian Praktikalitas E-Modul oleh Peserta Didik

\begin{tabular}{cccc}
\hline No & Aspek yang dinilai & $\boldsymbol{k}$ & Kategori Kepraktisan \\
\hline 1 & Kemudahan penggunaan & 0,83 & Sangat Tinggi \\
\hline 2 & Efisiensi waktu belajar & 0,78 & Tinggi \\
\hline 3 & Manfaat & 0,80 & Tinggi \\
\hline & Rata-rata & 0,80 & Tinggi \\
\hline
\end{tabular}

Sumber: Data Primer (2021)

Tabel 5 di atas menunjukkan bahwa hasil analisis penilaian praktikalitas oleh peserta didik memperoleh nilai rata-rata 0,80 dengan tingkat praktikalitas "tinggi". Komponen kemudahan penggunaan memperoleh nilai sebesar 0,83 dan masuk dalam kategori "sangat tinggi". Hal ini menunjukkan bahwa e-modul yang dikembangkan memiliki petunjuk penggunaan yang mudah

Jurnal Sikola: Jurnal Kajian Pendidikan dan Pembelajaran Vol. 3, No. 1, Th. 2021 
dipahami, penyajian materi jelas dan sederhana, keseluruhan isi dari e-modul mudah dipahami serta ukuran dan jenis huruf yang mudah dibaca. Hal ini sesuai dengan karakteristik e-modul yang dikemukakan oleh Daryanto dalam (Wulansari, \& Sri Kantun, 2018) yaitu self instruction dimana e-modul harus memiliki petunjuk yang jelas agar peserta didik mudah menggunakannya dan mengetahui tujuan pembelajaran seperti apa yang harus mereka capai.

Komponen efisiensi waktu belajar memperoleh nilai sebesar 0,78 dan masuk dalam kategori "tinggi", ini menunjukkan bahwa e-modul pembelajaran sosiologi membantu peserta didik belajar sesuai dengan kemampuan belajarnya sendiri. Menurut Daryanto dalam (Zainul, 2020) menjelaskan bahwa pembelajaran dengan menggunakan e-modul akan lebih efisien karena peserta didik belajar sesuai kecepatannya sendiri. Oleh karena itu, dapat disimpulkan bahwa e-modul pembelajaran sosiologi dapat membantu peserta didik belajar sesuai dengan kecepatan belajar yang dimilikinya.

Komponen manfaat memperoleh nilai sebesar 0,80 dan masuk dalam kategori "tinggi". Berdasarkan nilai yang diperoleh artinya e-modul membantu peserta didik untuk belajar mandiri, membantu peserta didik dalam memahami materi karena disajikan gambar yang bertujuan untuk mempermudah peserta didik memahami materi, sejalan dengan apa yang dikatakan Prastowo dalam (Istikomah \& Purwako, 2020) bahwa penggunaan gambar dalam modul sangat diperlukan karena akan menambah daya tarik sehingga akan mengurangi kebosanan peserta didik ketika mempelajarinya, e-modul pembelajaran sosiologi yang dikembangkan dapat meningkatkan semangat dan membuat pembelajaran menjadi lebih menyenangkan yang dilihat dari penilaian yang diberikan oleh peserta didik.

\section{Pembahasan}

Pengembangan e-Modul pembelajaran sosiologi yang dikembangkan terdiri dari judul, kata pengantar, daftar isi, peta konsep, petunjuk menggunakan modul, Kompetensi Inti (KI), Kompetensi Dasar (KD), tujuan pembelajaran, materi ajar, lembar kegiatan, evaluasi, glosarium dan daftar pustaka. Hal ini sesuai dengan teori yang menyatakan bahwa e-modul terdiri dari cover, bagian pendahuluan, kegiatan pembelajaran, latihan evaluasi, umpan balik dan daftar pustaka (Kemendikbud, 2017). Data yang diperoleh dalam penelitian ini adalah data validasi dan praktikalitas e-Modul pembelajaran sosiologi berbasis flipbook maker. Data validasi terdiri dari komponen kegrafikan, kebahasaan, kelayakan isi dan penyajian. E-modul yang dikembangkan dikatakan valid apabila e-Modul tersebut secara tepat, sahih dan dapat mengukur apa yang seharusya diukur (Latisma, 2011).

E-modul pembelajaran sosiologi berbasis flipbook maker divalidasi oleh 2 orang dosen sosiologi sebagai ahli media dan 1 orang guru sosiologi sebagai ahli materi. Validasi e-modul dilakukan dengan cara memberikan angket validasi kepada validator yang disusun berdasarkan skala likert. Hasil penilaian oleh ahli media pada komponen kegrafikan, yaitu 0,86 dan komponen kebahasaan memperoleh nilai 0,80. Maka rata-rata dari kedua komponen tersebut, yaitu 0,83 dengan kategori kevalidan "sangat tinggi". Hasil penilaian ahli materi terhadap komponen isi yaitu 0,89 dan komponen penyajian memperoleh nilai sebesar 0,87. Maka rata-rata dari kedua komponen tersebut, yaitu 0,88 dengan kategori kevalidan "sangat tinggi". Dari penjelasan tersebut maka e-Modul pembelajaran sosiologi berbasis flipbook maker dinyatakan valid atau layak digunakan dalam pembelajaran yang dilihat dari tabel kategori keputusan berdasarkan momen kappa oleh Landis dan Koch dalam (Watters, 2008). Hal ini sesuai dengan pernyataan (Arikunto, 2008) bahwa bahan ajar dikatakan valid jika bahan ajar tersebut dapat menunjukkan kondisi yang sudah sesuai dengan isi dan konstruknya.

Uji praktikalitas pada penelitian pengembangan ini dilakukan dengan cara memberikan angket praktikalitas kepada guru dan peserta didik. Menurut (Rochmad, 2012) bahan ajar dikatakan praktis apabila para ahli dan praktisi mengatakan bahwa secara teoritis bahan ajar yang dikembangkan dapat diterapkan dan keterlaksanaanya masuk dalam kategori baik. Hasil uji

Jurnal Sikola: Jurnal Kajian Pendidikan dan Pembelajaran Vol. 3, No. 1, Th. 2021 
praktikalitas yang telah dilakukan rata-rata nilai yang diperoleh dari guru yaitu 0,85 dan termasuk dalam kategori "sangat tinggi", sedangkan rata-rata nilai yang diperoleh dari angket peserta didik diperoleh nilai 0,80 dan termasuk dalam kategori "tinggi". Berdasarkan hasil penilaian yang diberikan oleh guru dan peserta didik maka e-Modul pembelajaran sosiologi masuk dalam kriteria praktis. Hal ini sesuai dengan penelitian (Kuncahyono, 2018) yang menyatakan bahwa respon pengguna e-Modul dalam pembelajaran menunjukkan e-Modul praktis dan membantu dalam pembelajaran tematik dan dapat digunakan secara mandiri oleh peserta didik dengan bantuan peralatan berbasis komputer. Selain dapat membantu dalam pembelajaran untuk meningkatkan pemahaman peserta didik, e-Modul berbasis flipbook maker praktis dalam hal penggunaan dan penyimpanannya. Hal ini sesuai dengan pendapat (Arikunto, 2008) yang menyatakan bahwa kepraktisan merupakan suatu kemudahan pada suatu instrumen evaluasi baik dalam mempersiapkan, menggunakan menginterpretasi memperoleh hasil maupun kemudahan dalam menyimpannya.

\section{Kesimpulan}

Pengembangan e-modul pembelajaran sosiologi berbasis flipbook maker menggunakan sebuah aplikasi yaitu aplikasi flipbook maker. Berdasarkan hasil penelitian, maka dapat disimpulkan bahwa telah dihasilkan sebuah e-modul pembelajaran sosiologi berbasis flipbook maker untuk peserta didik kelas XI IPS SMAN 1 Sawahlunto. Rata-rata penilaian validitas oleh ahli media memperoleh nilai 0,83 dengan kategori kevalidan "sangat tinggi" yang dinilai dari komponen kegrafikan dan komponen kebahasaan. Rata-rata penilaian validitas oleh ahli materi memperoleh nilai 0,88 dengan kategori kevalidan "sangat tinggi" yang dinilai dari komponen isi dan komponen penyajian. Maka dapat disimpulkan e-Modul yang telah dihasilkan valid sesui dengan yang dikemukakan oleh (Arikunto, 2008) bahwa bahan ajar dikatakan valid apabila dapat meninjukkan kondisi yang sudah sesuai dengan isi dan konstruknya. Rata-rata penilaian praktikalitas oleh guru dan peserta didik diperoleh nilai secara berturut-turut adalah 0,85 dan 0,80 dengan kategori kepraktisan dari guru "sangat tinggi" dan kategori kepraktisan dari peserta didik "tinggi" yang dinilai dari komponen kemudahan penggunaa, efisiensi waktu pembelajaran dan manfaat. Berdasarkan penilaian tersebut e-Modul yang dihasilkan praktis sesuai dengan yang dikemukakan oleh (Rochmad, 2012), yaitu bahan ajar dikatakan praktis apabila para ahli dan praktisi mengatakan bahwa secara teoritis bahan ajar yang dikembangkan dapat diterapkan dan keterlaksanaanya masuk dalam kategori baik.

\section{Daftar Pustaka}

Arikunto, S. (2008). Dasar-dasar Evaluasi Pendidikan. Jakarta: Bumi Aksara.

Asrial, A., Syahrial, S., Maison, M., Kurniawan, S. O. P. (2020). Ethnoconstructivism E-Module to Improve Perception, Interest, And Motivation of Students in Class V Elementary School. 9(1), 3041. https://doi.org/10.23887/jpi-undiksha.v9i1.19222

BNSP. (2013). Kegiatan Penilaian Buku teks Pelajaran Pendidikan Dasar dan Menengah. Jakarta: Departemen Pendidikan Nasional.

Budhi Oktavia, Rahadian Zainul, Guspatni, A. P. (2018). Pengenalan Dan Pengembangan E-Modul Bagi Guru- Guru.

Daryanto, D. (2014). Menyusun Modul: bahan untuk persiapan dalam mengajar. Yogyakarta: Gava Media.

Dewi, N. (2015). Merancang Pencapaian Kompetensi Dasar Melalui Perumusan Indikator. EBuletin, 1-11.

Henggraini Eka Putri, U. (2020). TThe DevelopmenT Of E-Modules Problem Based Learning Using Google Classroom For Basic Electricity And Electrinics At Vocational School. 4, 84-93. 
Yulia Wilki Rahayu, Erianjoni Erianjoni Pengembangan E-modul Pembelajaran Sosiologi Berbasis Flipbook Maker untuk Peserta Didik Kelas XI IPS SMAN 1 Sawahlunto

Istikomah, I \& Purwako, P. N. (2020). Pengembangan E-modul Matematika Berbasis Realistik untuk Meningkatkan Kemampuan Berfikir Kreatif Siswa. 7(2), 63-71.

Kemendikbud. (2017). Panduan praktis Penyusunan E-modul Tahun 2017. Jakarta: Direktorat Pembinaan Sekolah Menengah Atas.

Kuncahyono, K. (2018). Pengembangan E-Modul (Modul Digital) dalam Pebelajaran Tematik di SekolAH Dasar. 2(2), 219-231.

Latisma, L. (2011). Evaluasi Pembelajaran. Padang: UNP Press.

Nurhasikin, N., \& Kurnia Ningsih, T. T. (2019). Pengembangan Modul Berbasis Discovery Learning Materi Struktur dan Fungsi Jaringan Tumbuhan SMA. Pendidikan Informatika Dan Sains, 8, 163-178. https://doi.org/10.31571/saintek.v8.i2.1223

Prayudha, D. R. (2014). Pengembangan E-modul dengan Model Problem Based Learning pada Materi Bilangan Bulat Kelas VII. 48-56.

Priyanthi, K.A. \& Agustini, K. (2017). Pengembangan E-Modul Berbantuan Simulasi Berorientasi Pemecahan Masalah Pada Mata Pelajaran Komunikasi Data (Studi Kasus : Siswa Kelas XI TKJ SMK Negeri 3 Singaraja ). 6(2), 40-49.

Putri, I.P., \& Yuniasih, S. H. S. (2020). Pengembangan E-modul Berbasis Kvisoft Flipbook Maker Perjuangan Para Pahlawan di Kelas IV Sekolah Dasar. 4, 523-530.

Renat, S. E., \& Novriyanti, E. (2017). Pengembangan Modul Dilengkapi Peta Konsep dan Gambar pada Materi Keanekaragaman Makhluk Hidup untuk Siswa Kelas VII SMP Development of Module With Concept Maps and Picture on The Diversity of Living Things Materials for Students Class VII Junior High School. I(1), 95-109.

Rochmad, R. (2012). Desain Model Pengembangan Perangkat Pembelajaran Matematika. Kreano, 3.

Santika, A., \& Sylvia, I. (2021). Efektivitas E-Modul Berbasis Anyflip untuk Meningkatkan Kemampuan Penguasaan Materi Peserta Didik pada Materi Nilai dan Norma Sosial Kelas X di SMA N 3 Payakumbuh. Jurnal Sikola: Jurnal Kajian Pendidikan Dan Pembelajaran, 2(4), 285-296. https://doi.org/10.24036/sikola.v2i4.128

Sari, N. M., Erianjoni, E., \& Sylvia, I. (2019). Perilaku Siswa Menghadapi Ujian Nasional Berbasis Komputer di SMAN 3 Kota Pariaman Tahun 2018. Jurnal Perspektif, 2(1), 1-11. https://doi.org/10.24036/perspektif.v2i1.58

Shafa, S. (2014). Karakteristik Proses Pembelajaran Kurikulum 2013. Dinamika Ilmu, 14(32), 8196.

Suarsana, G. A. M. (2013). Pengembangan E-modul Berorientasi Pemecahan Masalah untuk Meningkatkan Keterampilan Berfikir Kritis Mahasisawa. 2(2), 264-275.

Watters, S. B. (2008). Statistics In A Nutshell A Desktop Quick Reference. United State of America: O'Reilley Media, Inc.

Wijayanto, M. S. Z. (2014). Pengembangan E-modul Berbasis Flip Book Maker dengan Model Projeck Based Learning untuk Meningktakan Kemampuan Pemecahan Masalah Matematika. Prosiding Matematika and Sciences Forum 2014, 625-628. Semarang.

Winaya, I. K. A., Darmawiguna, I. G. M., \& Sindu, I. G. P. (2017). PPengembangan E-Modul Berbasis Project Based Learning pada Mata Pelajaran Pemrograman Web Kelas X di SMK Negeri 3 Singajara. 13(2), 198-211.

Wulansari, E.V., Sri Kntun, P. S. (2018). Pengembangan E-modul Pembelajaran Ekonomi Materi Pasar Modal untuk Siswa Kelas XI IPS MAN 1 Jember Tahun Ajaran 2016/2017. Pendidikan Ekonomi, 12, 1-7. https://doi.org/10.19184/jpe.v12i1.6463

Zainul, A. (2020). Pengembangan E-Modul Larutan Penyangga Berbasis Discovery Learning Untuk Kelas XI SMA / MA. 2(1).

Jurnal Sikola: Jurnal Kajian Pendidikan dan Pembelajaran Vol. 3, No. 1, Th. 2021 